Folia Phoniatr. 1955;7:122-123

\title{
Dr. Emil Froeschels
}

Dr. Emíl Froeschels has become the living symbol of international logopedics, and congratulating him on the occasion of his 70th birthday is like erecting a milestone in the development of this science, the very name of which he has coined. If having become a living monument feels peculiar, Dr. Froeschels does not show any signs of it. His eager interest and gift of observation, expansive facility of communication and, last not least, his pervasive sense of humor continue unabated and have only deepened with the years. Watching every phase of the development, and spearheading many of the newest accomplishments of logopedics make him the most diligent and assiduous worker in our field. Founder in the past, leader in the present, he remains one of the promises of the future, thus belying the popular connotation of advanced age. This latter is only one of the many errors of opinion which Dr. Froeschels has been able to correct. His genius and untiring activity have been and remain one of the most reliable foundations of the science of speech and voice.

Some of his many friends, pupils and admirers have taken the opportunity of his 70th birthday to show their deep appreciation of his work by writing papers dedicated to Dr. Froeschels (who, in American parlance, might be called Mr. Logopedics). One of these papers is contained in this number, while the others will follow in future issues of Folia Phoníatríca.

Ad multos, multos annos...

In the name of Dr. Froeschels'’ friends and pupils, The Editorial Committee.

The Editors and Publishers of Folia Phoníatríca consider it an honor to extend to Dr. Emíl Froeschels their most sincere congratulations and to thank him warmly for his active cooperation and interest in the development of this Journal. 